\title{
SENAM BERSAMA MASYARAKAT DESA BONTOCINI
}

\author{
RATNASARI \\ 9173770410258 \\ ratna.sarhyi@gmail.com
}

1. Bentuk Kegiatan

> Senam bersama masyarakat desa Bontocini.

2. Lokasi

> Halaman Mesjid Al-ikhlas desa Bontocini.

3. Hari/Tanggal dan Waktu

Senin, 09 November 2020, pukul 15:30 - 17:00.

4. Peserta yang Dilibatkan

> Masyarakat desa Bontocini

> Mahasiswa KKLP Yapti Jeneponto

5. Alasan diadakannya

Alasan diadakannya kegiatan ini adalah untuk menjaga kebugaran jasmani. selain itu, senam juga dapat memperkuat tulang, membantu menormalkan aliran darah dan melatih urat saraf yang kaku serta meningkatkan kesehatan jantung dan stamina tubuh. 
6. Tujuan dan Manfaat

> Tujuan dan manfaat senam yaitu untuk membantu meningkatkan kebugaran jasmani serta dapat menjaga stamina tubuh.

7. Deskripsi Kegiatan

> Kegiatan senam ini dilakukan setelah sholat Ashar tempatnya yaitu di halaman mesjid Al-ikhlas desa Bontocini. Senam berlangsung selama kurang lebih 1 jam. 